\title{
Detection of Francisella tularensis in three vole species in Central Europe
}

Jeske, Kathrin; Tomaso, Herbert; Imholt, Christian; Schulz, Jana; Beerli, Olivia; Suchomel, Josef; Heroldova, Marta; Jacob, Jens; Staubach, Christoph; Ulrich, Rainer G.

\section{Published in:}

Transboundary and Emerging Diseases

Link to article, DOI:

10.1111/tbed.13078

Publication date:

2019

Document Version

Peer reviewed version

Link back to DTU Orbit

Citation (APA):

Jeske, K., Tomaso, H., Imholt, C., Schulz, J., Beerli, O., Suchomel, J., Heroldova, M., Jacob, J., Staubach, C., \& Ulrich, R. G. (2019). Detection of Francisella tularensis in three vole species in Central Europe. Transboundary and Emerging Diseases, 66(2), 1029-1032. https://doi.org/10.1111/tbed.13078

\section{General rights}

Copyright and moral rights for the publications made accessible in the public portal are retained by the authors and/or other copyright owners and it is a condition of accessing publications that users recognise and abide by the legal requirements associated with these rights.

- Users may download and print one copy of any publication from the public portal for the purpose of private study or research.

- You may not further distribute the material or use it for any profit-making activity or commercial gain

- You may freely distribute the URL identifying the publication in the public portal 
MS. JANA SCHULZ (Orcid ID : 0000-0002-5719-4542)

DR. RAINER ULRICH (Orcid ID : 0000-0002-5620-1528)

Article type : Short Communication

Detection of Francisella tularensis in three vole species in Central Europe

Short running title: Francisella tularensis in voles

\section{Kathrin Jeske $^{1}$, Herbert Tomaso ${ }^{2}$, Christian Imholt ${ }^{3}$, Jana Schulz ${ }^{4,5}$, Olivia Beerli ${ }^{6}$, Josef}

Suchomel $^{7}$, Marta Heroldova ${ }^{8}$, Jens Jacob ${ }^{3}$, Christoph Staubach ${ }^{4}$, and Rainer G. Ulrich ${ }^{1 *}$

${ }^{1}$ Friedrich-Loeffler-Institut, Institute of Novel and Emerging Infectious Diseases, Greifswald - Insel Riems, Germany; ${ }^{2}$ Friedrich-Loeffler-Institut, Institute of Bacterial Infections and Zoonoses, Jena, Germany; ${ }^{3}$ Julius Kühn-Institute, Institute for Plant Protection in Horticulture and Forests, Vertebrate Research, Münster, Germany; ${ }^{4}$ Friedrich-Loeffler-Institut, Institute of Epidemiology, Greifswald Insel Riems, Germany; ${ }^{5}$ Technical University of Denmark, National Veterinary Institute, Kgs. Lyngby, Denmark; ${ }^{6}$ Institut für Parasitologie, Universität Zürich, Zürich, Switzerland, ${ }^{7}$ Faculty of AgriSciences, Department of Zoology, Fisheries, Hydrobiology and Apiculture, Mendel University in Brno, Brno, Czech Republic, ${ }^{8}$ Department of Forest Ecology, Mendel University in Brno, Brno, Czech Republic.

*Correspondence: Rainer G. Ulrich, Friedrich-Loeffler-Institut, Institute of Novel and Emerging Infectious Diseases, Greifswald - Insel Riems, Germany. Email: Rainer.Ulrich@fli.de

This article has been accepted for publication and undergone full peer review but has not been through the copyediting, typesetting, pagination and proofreading process, which may lead to differences between this version and the Version of Record. Please cite this article as doi: 10.1111/tbed.13078

This article is protected by copyright. All rights reserved. 
Funding information: European Union, EMIDA-ERA-NET project "harmonized Approaches in monitoring wildlife Population Health, and Ecology and Abundance" (APHAEA) through Bundesamt für Landwirtschaft und Ernährung (BLE) (2811ERA117); Federal Environment Agency (UBA) within the Environment Research Plan of the German Federal Ministry for the Environment, Nature Conservation, Building and Nuclear Safety (BMUB) (grant number 371348 401).

\section{Abstract}

Francisella tularensis is a zoonotic, gram-negative bacterium that causes tularemia in humans. Depending on its subspecies and the route of transmission, mild to lethal courses have been reported. F. tularensis subsp. holarctica is the only subspecies found in Europe and affects a plenitude of vertebrates including lagomorphs and rodents. Population outbreaks of certain rodent species are likely to be involved in the transmission of this pathogen. This molecular survey aims to evaluate the presence of $F$. tularensis in small mammals from three Central European countries. Using a real-time polymerase chain reaction, F. tularensis DNA was detected in common voles (Microtus arvalis) from Switzerland and in field voles (Microtus agrestis) and a bank vole (Myodes glareolus) from Germany, but not in any other small mammal species. All common voles from the Czech Republic were negative for $F$. tularensis DNA. The prevalence in the three vole species varied between $1.3 \%$ and 3.0\%. In conclusion, Francisella tularensis DNA was detected in three vole species in two of three countries investigated. The observed low prevalence raises questions on the role of voles for the transmission of Francisella tularensis in Central Europe.

KEYWORDS: Bank vole, Common vole, Czech Republic, Field vole, Germany, Switzerland, Tularemia

\section{INTRODUCTION}

Tularemia is a zoonotic disease in humans with a flu-like onset. Later, symptoms differ depending on the route of pathogen entry. The disease is caused by the gram-negative bacterium Francisella tularensis, which can infect a broad range of invertebrates and vertebrates. In Europe, rodents and 
lagomorphs are thought to act as main amplification hosts (Rossow et al., 2014). Transmission to humans can occur through contact with infected mammals, arthropods or contaminated water (LuqueLarena et al., 2017). The objective of this molecular survey was to evaluate the occurrence of $F$. tularensis in small mammals, and voles in particular, in Central Europe.

\section{MATERIAL AND METHODS}

Small mammals were collected according to a standard protocol for snap trapping (Drewes et al., 2016): (1) during late fall 2014 at three grassland grids close to Brno, Czech Republic, (2) during spring, summer and fall 2014 at grassland and forest grids in three federal states of Germany, and (3) at two sites in Zurich, Switzerland, namely Almend and Fildern (Figure S1). In the Czech Republic trapping was performed under the supervision of a person with a certificate of professional competence to design experiments and projects according to $\S 15$ d paragraph 3 of law 246/1992 (certificate CZ 01270). In Germany, all procedures involving animals were conducted according to relevant legislation and by permission of the federal authorities (Regierungspräsidium Stuttgart: 359185.82/0261, Landesamt für Landwirtschaft, Lebensmittelsicherheit und Fischerei MecklenburgVorpommern: 7221.3-030/09, Thüringer Landesamt für Lebensmittelsicherheit und Verbraucherschutz: 22-2684-04-15-107/09). Trapping in Switzerland was performed under the direct supervision of a veterinary specialist, and according to the Swiss law, the guidelines on Animal Welfare and the specific regulations of the Canton of Zurich (permit number 17/2013 by the Veterinary Office and the Ethics Committee of the Canton of Zurich; Kantonales Veterinäramt Zürich, Zürich, Switzerland). Small mammal dissection and species confirmation followed established standard protocols (Fischer et al., 2018). DNA was isolated from spleen tissue samples using QIAamp DNA Mini Kit (Qiagen, Hilden, Germany) and analyzed by a real-time polymerase chain reaction (PCR) assay targeting the F. tularensis-specific tul4 gene (Versage et al., 2003). A conventional duplex PCR was used for the identification of subspecies holarctica (Fabbi et al., 2016). An isolation attempt using spleen tissue was performed on cysteine heart agar at $37^{\circ} \mathrm{C}$ and $5 \% \mathrm{CO}_{2}$ (Tomaso et al., 2018). The 95\% confidence interval (CI) was estimated using the statistical software package $\mathrm{R}$ (http://www.r-project.org).

This article is protected by copyright. All rights reserved. 


\section{RESULTS}

A total of 767 small mammals were collected for this molecular survey, with 151 common voles originating from Brno, Czech Republic, 347 small mammals from Germany and 269 voles of four species from Switzerland (Table 1). Nine out of 737 (1.2\%, CI: 0.6-2.3\%) small mammals were tested to be positive for $F$. tularensis DNA (Table 1). Subspecies identification revealed exclusively $F$. tularensis subspecies holarctica. The isolation attempt failed for all samples (data not shown). In Switzerland five of 167 (3.0\%, CI: 1.0-6.8\%) common voles were found to be Francisella DNA positive (Table 1), whereas in Germany none of the common voles, but three of 104 (2.9\%, CI: 0.6$8.2 \%)$ field voles and one of 78 (1.3\%, CI: 0.0-6.9\%) bank voles were found to be Francisella DNA positive (Table 1; Fig. S2A). All common voles from the Czech Republic were tested negative. Positive animals were all trapped in fall 2014 (Figs. S2A and S2B). In Germany only animals from one of three grids at Gotha, Thuringia, in grassland habitat with a nearby forest, were found to be positive. All animals from the other grids in Gotha and the other sites in Mecklenburg-Western Pomerania and Baden-Wuerttemberg were negative (data not shown).

\section{DISCUSSION}

The detection of Francisella DNA in common vole, field vole and bank vole is in agreement with previous studies in Germany and Finland (Kaysser et al., 2008; Rossow et al., 2014), and confirms the susceptibility of these vole species for F. tularensis subsp. holarctica. Its detection in voles from Germany and Switzerland is also in line with its previous detection in potential vectors and reservoirs in these countries and an increasing incidence of human tularemia cases (Kaysser et al., 2008). However, in Switzerland F. tularensis was detected before in house mice (Mus musculus domesticus), but not in voles (Origgi et al., 2015). In contrast to an earlier detection of this pathogen in a common vole in the Czech Republic (Treml et al., 2001), the current investigation failed to detect any Francisella DNA in common voles from this country. This finding might be explained by a focal occurrence of the pathogen (Pavlovsky \& Levine, 1966). Similarly, Francisella DNA was detected only in voles from one of three grids in Thuringia, but not in Baden-Wuerttemberg, although human tularemia cases were reported in 2014 from both German federal states (Robert-Koch-Institut, 2015).

This article is protected by copyright. All rights reserved. 
A similar spatial Francisella occurrence was observed in a study in Sweden where subpopulations of F. tularensis could only be detected within areas of $2 \mathrm{~km}^{2}$ (Svensson et al., 2009).

The average prevalence of $F$. tularensis in this study was $1.2 \%$, which is comparable to results of studies in wild small mammal populations in Finland and Iran during non-outbreak situations with prevalences ranging from 0.9 to $1.9 \%$ (Rossow et al., 2014; Mostafavi et al., 2018). In case of known foci or recent outbreaks of F. tularensis in China, Germany and Spain prevalence may reach $4.8 \%$ to $20 \%$ depending on area and rodent population dynamics (Kaysser et al., 2008; Rodriguez-Pastor et al., 2018; Zhang et al., 2006). In our study the prevalences in bank voles (1.3\%), field voles (2.9\%) and common voles $(3.0 \%)$ were lower than the prevalences observed during an outbreak study in Lower Saxony, Germany, with prevalences of $4.5 \%, 10 \%$ and $8 \%$, respectively (Kaysser et al., 2008). The highest prevalence in common voles was measured during a recent tularemia outbreak in Spain with 34\% (Rodriguez-Pastor et al., 2018).

The failure of the isolation attempt might have been caused by our workflow including snap-trapping and freeze-thaw-cycles of carcasses and spleen samples. Previous isolation attempts using fresh spleen samples from hares demonstrated the successful performance of the isolation protocol in general (Tomaso et al., 2018).

In conclusion, this study detected Francisella DNA in voles of three species in Germany and Switzerland. Future detailed studies are warranted to confirm and characterize the potential hotspot distribution of Francisella in Central Europe and to evaluate if this could be used in control measures to prevent human infections. For this purpose a widespread network of wildlife monitoring and surveillance in Europe should be established for F. tularensis and other relevant pathogens.

\section{ACKNOWLEDGEMENTS}

We kindly acknowledge Marie-Pierre Ryser-Degiorgis, Thijs Kuiken, Ezio Ferroglio and Christian Gortazar for setting up and supporting the project APHAEA. We are grateful to Thijs Kuiken and Daniel Hegglin for critical reading of the manuscript, Kerstin Cerncic, Anja Hackbart and Byrgit Hofmann for excellent technical assistance, Franz J. Conraths and Peter Deplazes for their support, Ann-Kathrin Güttner for statistical analyses, Patrick Wysocki for generation of Figure S1, Christin

This article is protected by copyright. All rights reserved. 
Trapp and Daniela Reil for small mammal trapping in Germany and Stefan Fischer, Dörte Kaufmann, Anke Mandelkow, Marie Luisa Schmidt, Hanan Sheikh Ali, Stephan Drewes and Elisa Heuser for support of rodent trapping, dissections and cytochrome $b$ analysis.

\section{CONFLICT OF INTEREST STATEMENT}

The authors declare that they have no competing interests.

This article is protected by copyright. All rights reserved. 


\section{References}

Drewes, S., Schmidt, S., Jacob, J., Imholt, C., \& Ulrich, R. G. (2016, Accessed November 2016). APHAEA/EWDA Species Card: Voles - Mice. Retrieved from http://www.aphaea.org/cards/species/voles.

Fabbi, F., Prati, P., \& Genchi, M. (2016, Accessed November 2016). APHAEA/EWDA Diagnosis card: Tularaemia. Retrieved from www.aphaea.org/cards/diagnosis/tularaemia.

Fischer, S., Mayer-Scholl, A., Imholt, C., Spierling, N. G., Heuser, E., Schmidt, S., Reil, D., Rosenfeld U. M., Jacob, J. Nockler K. \& Ulrich, R. G. (2018). Leptospira Genomospecies and Sequence Type Prevalence in Small Mammal Populations in Germany. Vector Borne Zoonotic Dis, 18(4), 188-199. doi:10.1089/vbz.2017.2140

Kaysser, P., Seibold, E., Matz-Rensing, K., Pfeffer, M., Essbauer, S., \& Splettstoesser, W. D. (2008). Re-emergence of tularemia in Germany: presence of Francisella tularensis in different rodent species in endemic areas. BMC Infect Dis, 8, 157. doi:10.1186/1471-2334-8-157

Luque-Larena, J. J., Mougeot, F., Arroyo, B., Vidal, M. D., Rodriguez-Pastor, R., Escudero, R., Anda, P., Lambin, X. (2017). Irruptive mammal host populations shape tularemia epidemiology. PLoS Pathog, 13(11), e1006622. doi:10.1371/journal.ppat.1006622

Mostafavi, E., Ghasemi, A., Rohani, M., Molaeipoor, L., Esmaeili, S., Mohammadi, Z., Mahmoudi, A., Aliabadian M., \& Johansson, A. (2018). Molecular survey of tularemia and plague in small mammals from Iran. Front Cell Infect Microbiol. 8:215. doi:10.3389/fcimb.2018.00215

Origgi, F. C., Konig, B., Lindholm, A. K., Mayor, D., \& Pilo, P. (2015). Tularemia among freeranging mice without infection of exposed humans, Switzerland, 2012. Emerg Infect Dis, 21(1), 133-135. doi:10.3201/eid2101.140906

Pavlovsky, E. N., \& Levine, N. D. (1966). Natural nidality of transmissible diseases: with special reference to the landscape epidemiology of zooanthroponoses. University of Illinois Press.

Robert-Koch-Institut. (2015). Infektionsepidemiologisches Jahrbuch meldepflichtiger Krankheiten für 2014. Jahresbericht. Retrieved from http://www.rki.de/DE/Content/Infekt/Jahrbuch/Jahrbuch_2015.pdf?_blob=publicationFile

Rodriguez-Pastor, R., Escudero, R., Lambin, X., Vidal, M. D., Gil, H., Jado I., Rodriguez-Vargas, M.,

This article is protected by copyright. All rights reserved. 
Luque-Larena, J.J., \& Mougeot, F. (2018). Zoonotic pathogens in fluctuating common vole (Microtus arvalis) populations: occurrence and dynamics. Parasitology. 1-10. doi:10.1017/s0031182018001543

Rossow, H., Sissonen, S., Koskela, K. A., Kinnunen, P. M., Hemmila, H., Niemimaa, J., Huitu, O., Kuusi, M., Vapalahti, O., Henttonen, H., \& Nikkari, S. (2014). Detection of Francisella tularensis in voles in Finland. Vector Borne Zoonotic Dis, 14(3), 193-198. doi:10.1089/vbz.2012.1255

Svensson, K., Back, E., Eliasson, H., Berglund, L., Granberg, M., Karlsson, L., Larsson, P., Forsman, M., \& Johansson, A. (2009). Landscape epidemiology of tularemia outbreaks in Sweden. Emerg Infect Dis, 15(12), 1937-1947. doi:10.3201/eid1512.090487

Tomaso, H., Otto, P., Peters, M., Suss, J., Karger, A., Schamoni, H., Zuchantke E., \& Hotzel, H. (2018). Francisella tularensis and other bacteria in hares and ticks in North Rhine-Westphalia (Germany). Ticks Tick Borne Dis, 9(2), 325-329. doi:10.1016/j.ttbdis.2017.11.007

Treml, F., Hubalek, Z., Halouzka, J., Juricova, Z., Hunady, M., \& Janik, V. (2001). [Analysis of the incidence of tularemia in the Breclav District 1994-1999]. Epidemiol Mikrobiol Imunol, 50(1), 4-9.

Versage, J. L., Severin, D. D., Chu, M., C.\& Petersen, J. M. ( 2003). Development of a multitarget real-time TaqMan PCR assay for enhanced detection of Francisella tularensis in complex specimens. J Clin Microbiol, 41(12), 5492-5499.

Zhang, F., Liu, W., Chu, M. C., He, J., Duan, Q., Wu, M., Zhang, P. H., Zhao, Q. M., Yang, H., Xin, Z.T., \& Cao, W. C. (2006). Francisella tularensis in rodents, China. Emerg Infect Dis, 12(6), 994-996.

This article is protected by copyright. All rights reserved. 
TABLE 1. Detection of Francisella tularensis in small mammals from the Czech Republic, Germany and Switzerland. Positive results are shown in bold.

\begin{tabular}{|c|c|c|c|c|}
\hline Country & \multicolumn{2}{|l|}{ Species } & $\begin{array}{l}\text { Number of } \\
\text { captured } \\
\text { animals }\end{array}$ & $\begin{array}{l}\text { Number of PCR positive/ } \\
\text { total number of sampled } \\
\text { animals and } \\
\text { percentage }[\mathrm{CI}]\end{array}$ \\
\hline $\begin{array}{l}\text { Czech } \\
\text { Republic }\end{array}$ & Common vole & Microtus arvalis & 151 & $0 / 147 *$ \\
\hline \multirow[t]{9}{*}{ Germany } & Striped field mouse & Apodemus agrarius & 4 & $0 / 4$ \\
\hline & Yellow-necked mouse & Apodemus flavicollis & 56 & $0 / 48^{*}$ \\
\hline & Wood mouse & Apodemus sylvaticus & 6 & $0 / 6$ \\
\hline & Field vole & Microtus agrestis & 106 & $3 / 104 * 2.9 \%[0.6-8.2 \%]$ \\
\hline & Common vole & Microtus arvalis & 50 & $0 / 44^{*}$ \\
\hline & Bank vole & Myodes glareolus & 85 & $1 / 78 * 1.3 \%[0.0-6.9 \%]$ \\
\hline & Common shrew & Sorex araneus & 31 & $0 / 30^{*}$ \\
\hline & Crowned shrew & Sorex coronatus & 7 & $0 / 7$ \\
\hline & Eurasian pygmy shrew & Sorex minutus & 2 & $0 / 1^{*}$ \\
\hline Sub-total & & & 347 & $4 / 322 * 1.2 \%[0.3-3.1 \%]$ \\
\hline \multirow[t]{4}{*}{ Switzerland } & Montane water vole & Arvicola scherman & 65 & $0 / 65$ \\
\hline & Field vole & Microtus agrestis & 9 & $0 / 9$ \\
\hline & Common vole & Microtus arvalis & 168 & $5 / 167 * 3.0 \%[1.0-6.8 \%]$ \\
\hline & Bank vole & Myodes glareolus & 27 & $0 / 27$ \\
\hline Sub-total & \multicolumn{2}{|c|}{ 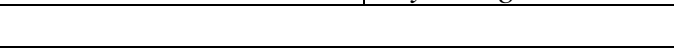 } & 269 & $5 / 268 * 1.9 \%[0.6-4.3 \%]$ \\
\hline Total & \multicolumn{3}{|c|}{\begin{tabular}{|l|l|} 
& 767 \\
\end{tabular}} & $9 / 737 * 1.2 \%[0.6-2.3 \%]$ \\
\hline
\end{tabular}

CI, confidence interval

* Differences between total number of captured and analysed animals is caused by missing spleen samples for a few animals.

\section{SUPPORTING INFORMATION}

Supporting information can be found online.

This article is protected by copyright. All rights reserved. 